\title{
Religious Faith and Contemporary Attitudes
}

Link to publication record in Manchester Research Explorer

\section{Citation for published version (APA):}

Mcandrew, S., McAndrew, S., Park, A. (Ed.), Curtice, J. (Ed.), Thomson, K. (Ed.), Phillips, M. (Ed.), Clery, E. (Ed.), \& Butt, S. (Ed.) (2010). Religious Faith and Contemporary Attitudes. In British Social Attitudes: The 26th Report (pp. 87-113). Sage Publications Ltd.

\section{Published in:}

British Social Attitudes: The 26th Report

\section{Citing this paper}

Please note that where the full-text provided on Manchester Research Explorer is the Author Accepted Manuscript or Proof version this may differ from the final Published version. If citing, it is advised that you check and use the publisher's definitive version.

\section{General rights}

Copyright and moral rights for the publications made accessible in the Research Explorer are retained by the authors and/or other copyright owners and it is a condition of accessing publications that users recognise and abide by the legal requirements associated with these rights.

\section{Takedown policy}

If you believe that this document breaches copyright please refer to the University of Manchester's Takedown Procedures [http://man.ac.uk/04Y6Bo] or contact uml.scholarlycommunications@manchester.ac.uk providing relevant details, so we can investigate your claim.

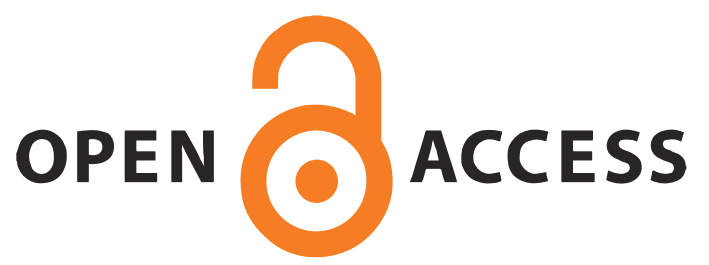


Park, A., Curtice, J., Thomson, K., Phillips, M., Clery, E. and Butt, S. (eds.) (2010), British Social Attitudes: the $26^{\text {th }}$ Report, London: Sage

\title{
5 Religious faith and contemporary attitudes
}

\author{
Siobhan McAndrew"
}

British society has become more secular over recent decades. Between 1983 and 2008 there was a sharp fall in the proportion of people who feel they belong to a particular religion and in the numbers who attend religious services frequently: from 69 to 56 per cent (identifying with a particular religion) and from 13 to 10 per cent (weekly or more frequent attendance). Belief in God has also declined, from 64 per cent in 1991 to 48 per cent in 2008. There appears to be a generational decline in the proportion of respondents reporting that religious beliefs make a difference to their lives (Crockett and Voas, 2006).

At the same time, immigration and demographic change has led to a rise in affiliation to other world religions and pentecostal Christianity, and an apparent religious renewal among second and subsequent generations of arrivals. ${ }^{1}$ Since this has occurred concomitantly with religious decline among the majority population, it appears that some polarisation of belief has occurred.

Over the last few decades, the issues which religious communities encounter have also changed markedly - the implications of technological change, for example, or the changing relationships and structures within British society. Religious authorities will often have unique moral messages about many of these developments and will attempt to impart these to their followers, albeit with varying degrees of success. In so doing, they will face increasing competition from other sources of moral authority. Given that immigrant communities in Britain are somewhat residentially concentrated, it is also conceivable that political parties might attempt to mobilise them on either religious or ethnic bases to maximise their share of the vote.

In this chapter we will explore these issues by examining the extent to which religious beliefs are linked to wider social attitudes more generally. We will focus on four areas of particular contemporary relevance:

- The first relates to bioethics, with long-standing questions about abortion rights and the acceptability of assisted dying having been debated

\footnotetext{
"Siobhan McAndrew is a Research Associate at the Institute for Social Change, University of Manchester.
} 
throughout 2008. The culpability of those assisting suicide was tested at the High Court, while the Human Rights and Embryology Bill was debated in Parliament, with considerable lobbying against it by pro-life organisations. ${ }^{2}$

- The second area of relevance reflects the proliferation of new and complex family forms over the last few decades (Duncan and Phillips, 2008). Here we will examine people's attitudes towards personal relationships and family roles, focusing on issues such as sex outside marriage, homosexual rights, and gender roles within the family.

- We next examine the evidence for any relationship between religion and party political choices. It was traditionally thought that class loyalty formed the bedrock of politics in Britain, and that any political cleavage along religious lines at least within Great Britain, if not Northern Ireland, ended in 1922 when the 'Irish question' was finally answered with the creation of the Irish Free State. However, there has been some reassessment of this apparent lack of a relationship between religiosity and party support. The fact that some traditional loyalties are dissolving, and that immigration is changing the religious profile of certain areas, means that religion and social questions may be emerging as a site for mobilisation.

- Finally, we focus upon the possible links between 'social trust' and religion. Do the religious in Britain have the high levels of social trust often claimed for their US counterparts?

How might religion be linked to a person's attitudes and values? Some have argued that religiosity - like sex, education or class - directly helps shape political views and party choices (Andersen et al., 2005). But religion could also have a more subtle effect on people's attitudes and values by influencing the choices they make about their peers, networks and organisations - in sum, the contexts which provide cues and information on socio-political issues. So religious peers or spouses, and religious environments such as churches and mosques, may well help shape attitudes towards a range of ethical issues and political preferences (Kotler-Berkowitz, 2001). Finally, relationships between religiosity and social attitudes could be confounded by personality differences: it is plausible that those seeking certainty in the religious domain do likewise in other areas of their lives.

\section{Measures of religiosity}

We begin by considering how best to measure a person's religiosity. In so doing, we ideally need to take account of the different dimensions that can make 
up religious faith and practise. For example, someone who is intensely personally religious - who prays every day and believes strongly in God and in the existence of an afterlife - might not attend religious services regularly. Another person might exhibit a high degree of practise - such as high involvement in organised religious activities - but not subscribe to the tenets of any religious faith. So relying on one measure, such as attendance at religious services, will only give a partial picture of someone's overall faith.

As far back as the 1960s, with the earliest large-scale surveys of religion, some writers have suggested that religiosity has different dimensions, each of which have different implications for social behaviour (Glock, 1962; Glock and Stark, 1968). For example, some US studies distinguish between belonging (affiliation), behaving (attendance and private practice) and believing (Leege and Kellstedt, 1993). This suggests that religiosity has at least three dimensions. A very recent study assumed that two dimensions exist and used a typology to distinguish Swiss survey respondents according to whether they were 'believers' or 'belongers' (Nicolet and Tresch, 2009). Here researchers tried to capture the form of religiosity characterised by a sense of institutional affiliation with long-standing churches, as well as post-traditional forms characterised by more individualised beliefs, where institutional affiliation may not be a given. They found that people exhibiting belief were more socially liberal than those who reported affiliation alone, while among the non-practising, significant differences existed between uncommitted Christians, 'believers without belonging', and the unreligious in selected political attitudes. It seems, therefore, that how you are religious matters as well as how far you are religious.

How might we capture this insight? A variety of methods can be used. For simple comparisons it is often enough to use a simple typology - such as the 'more religious', the 'unreligious' and those in between who may either believe in God without practising greatly or practise religion without believing strongly. Then, the characteristics of the more religious compared with the less religious can be illustrated in a straightforward and intuitive manner. Alternatively, we can use a more sophisticated scale which scores people according to their responses to a wider range of questions. We will now explore each of these options.

\section{The religious, the unreligious and the 'fuzzy faithful'}

Here we categorise respondents according to their responses to three questions: whether they identify with a particular religion, whether they believe in God and whether they attend religious services. We explored various ways of using these questions to divide up respondents. In particular, while it makes sense to distinguish between the highly religious (who believe in God, report an affiliation and attend services at least sometimes) and the unreligious (who do none of these things), it is less clear how to examine the intermediate group. It seems plausible that those who believe without reporting an affiliation 
(believers without belonging) might be distinct from those who report an affiliation but do not believe (belongers without believing). It also seems plausible that those who report belief and affiliation, but attend religious services less regularly than once a month, might still be distinctive compared with those who exhibit weaker beliefs or behaviours (the somewhat religious compared with the less religious). After some analysis, however, differences between these various intermediate groups were not readily apparent, and so, following the approach adopted by Voas and Ling elsewhere in this report (see in particular Table $4.6 \mathrm{p} .71$ ), we group this middle group together as the 'fuzzy faithful' (Voas, 2009). So we find little evidence for either a distinct group of socially traditional churchgoers who are secular in terms of belief or a group exhibiting intense post-traditional spirituality which is not linked to institutional forms.

In summary, our typology identifies three groups:

- The religious: Those who believe in God, belong to a religious group and attend religious services at least sometimes. Even on this broad definition of religiosity, this group comprises 28 per cent of respondents. We might expect this group to have attitudes which are distinct from the rest of the population.

- The fuzzy faithful: Those who exhibit some evidence of religious belief, affiliation or practice, either through belief in God, reporting a religious affiliation, or at least some attendance (but not all three). This category is likely to capture those with weak or no belief in a deity, or a weaker but residual loyalty to religious organisations and practices. This group covers 39 per cent of respondents.

- The unreligious: Those who neither believe in God nor belong to any religious group. We might consider this group to be the most clearly secularised. This group forms 33 per cent of respondents.

\section{The religiosity scale}

A second way of examining the impact of religiosity on socio-political attitudes and practices is to create a composite scale of religiosity. This method uses a larger number of items relating to personal religiosity and religious practise than the three used in the typology we have just discussed. Each individual is given a score depending on their responses to this wider set of questions, so that we can distinguish more clearly between the highly religious and the less religious. Fourteen items were used to create the scale, encompassing the following:

- being a member of a particular religious group

- being brought up in a particular religious group 
- church attendance

- participation in church activities

- importance of religion in the respondent's daily life

- the respondent's self-perception as religious or not

- prayer

- belief in God

- belief in heaven

- belief in hell

- belief in the afterlife

- confidence in churches and religious organisations

- response to the proposition that we trust too much in science and not enough in religious faith

- response to the proposition that religion helps people find inner peace and happiness.

Some questions involve religious attitudes and behaviours which are so mild that even many agnostic or atheist respondents might indicate assent - such as the question regarding whether religion helps people find inner peace. Others are stronger: many highly religious people might yet report low levels of confidence in formal religious organisations or indicate that we do not trust 'too much' in science. Including such questions helps us distinguish between the unreligious who are yet favourably disposed in some way towards religion, and those who are not; and the religious who report pro-religious attitudes and behaviours across the board, and those who do not. In addition, we include three questions relating to belief in the afterlife, belief in heaven and belief in hell, because prior work has indicated that the less religious may reject belief in a traditional heaven but yet believe in an afterlife, and also that those who believe in heaven may yet reject the notion of a traditional hell (Branas-Garza et al., forthcoming). ${ }^{3}$

To create the scale, the original answers to each of the fourteen questions were dichotomised to distinguish between those reporting at least a moderate level of belief or practice in the relevant question (scored as 1) and the rest (scored as 0 ). The scale was then created by simply adding the scores across the fourteen items for each individual. Further details are given in the appendix to this chapter. The maximum possible score was 14 and the minimum 0 , with a mean score of $6.6 .^{4}$

Figure 5.1 shows the distribution of responses along this religiosity scale in terms of the percentage of respondents given each score. The distribution of these scores is interesting: there appear to be two different peaks around which the scores are centring, with a religious peak, an unreligious peak and a group in between. This suggests that even with a larger array of measures of religiosity the threefold typology described earlier characterises respondents fairly. This is 
confirmed by Table 5.1, which gives the mean religiosity score for each of the three groups: the religious, the fuzzy faithful and the unreligious.

Figure 5.1 Distribution of scores on the religiosity scale

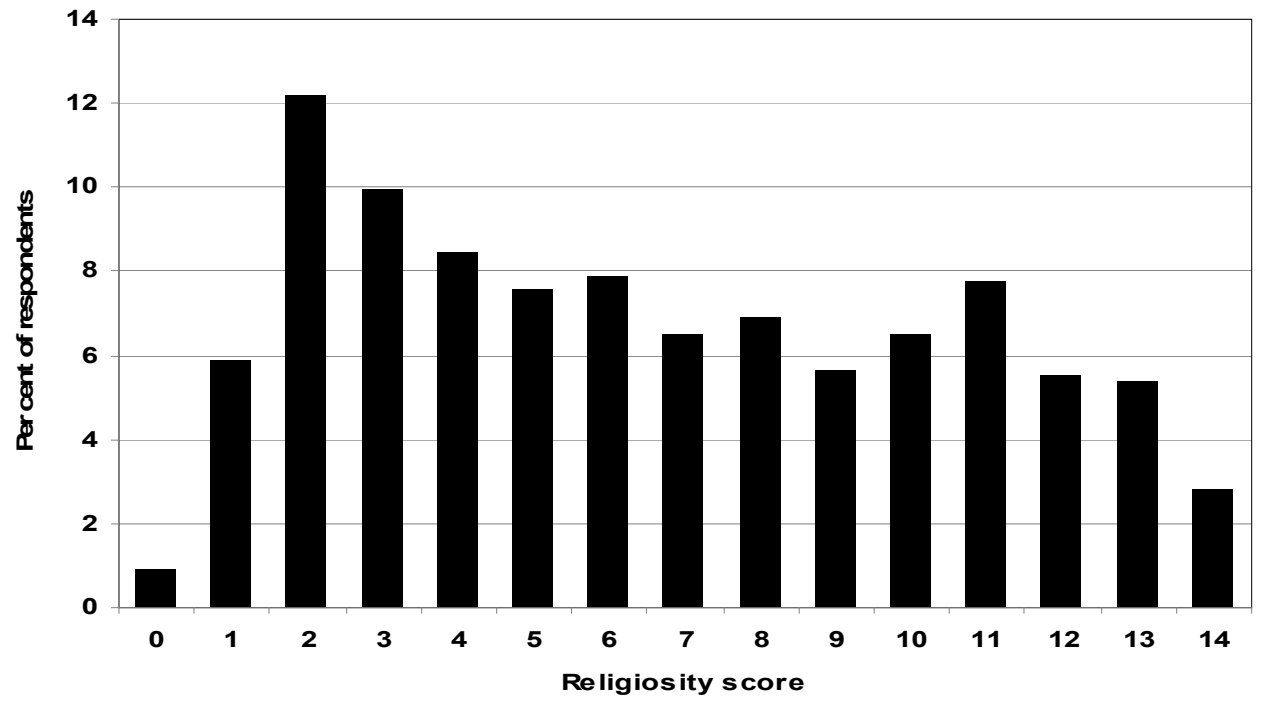

The data on which Figure 5.1 is based can be found in the appendix to this chapter

Table 5.1 Religiosity scores for the religious, fuzzy faithful and unreligious

\begin{tabular}{lcr}
\hline Religiosity type & Mean score on religiosity scale & Base \\
Religious & 11.0 & 528 \\
Fuzzy faithful & 6.7 & 791 \\
Unreligious & 2.8 & 623 \\
All & 6.6 & 1942 \\
\hline
\end{tabular}

\section{Dimensions of religiosity}

We also carried out further analysis of these same fourteen questions to examine whether there are different types of religiosity. We did this by drawing on the extra information given in the responses as to the greater or lesser frequency of prayer, for example, or the intensity of self-assessed religiosity (the additive scale method simply captures whether the respondent engages in prayer or not, 
or identifies as religious or not). ${ }^{5}$ Three dimensions of religiosity emerged as significant. The first accounts for the greatest variation, and relates to the following: whether the respondent is a religious adherent, whether they consider religion important in their everyday life, and whether they describe themselves as religious, believe in God, the afterlife and heaven, attend church regularly, and have confidence in churches. We can call this generalised religiosity generalised in the sense that it is not specific to particular religious behaviours. The second dimension is associated most strongly with belief in an afterlife, heaven and hell. Belief in God is not associated with this dimension, which might seem surprising, given that belief in a personal God is a key aspect of most traditional religions in Britain. Neither is religious adherence associated with this dimension, while church attendance is negatively associated. So we might call this dimension one of diffuse belief without belonging. ${ }^{6}$ Given the lack of association with adherence, belief in God and attendance, this dimension of religiosity seems to be one which our threefold typology fails to pick up. The third dimension encompasses people who were brought up in a particular religion, but indicators of religious activity such as church attendance are negatively associated. Adherence also correlates weakly with this dimension. We might consider this dimension to be one of religious background, where people have been brought up in a family with a religious identification but do not currently believe or practice; their religiosity may be of a more nominal type.

We will now use the religiosity typology to examine how religiosity appears linked to people's views about key contemporary issues. ${ }^{7}$

\section{Bioethics and religion}

We begin by examining public attitudes towards a range of bioethical issues. While the relationship between religiosity and attitudes towards abortion and euthanasia is well established, their high salience over the last few years makes it important to examine them afresh. The Human Rights and Embryology Bill was debated in Parliament during 2008, covering the creation of hybrid embryos for research, and the creation of 'saviour siblings'. An amendment by the 'prolife' Conservative MP Nadine Dorries also proposed that the upper term limit for abortion be reduced. The legalisation of euthanasia was actively debated during the same period, reflecting Debbie Purdy's campaign to have the law on assisting suicide clarified, as well as ongoing discussions about the ethics of the Dignitas clinic in Switzerland.

We assessed public attitudes in this area through the following questions:

Do you think it is wrong to have an abortion if there is a strong chance of serious defect in the baby?

Do you think it is wrong to have an abortion if the family has a very low income and cannot afford any more children? 
People have different views about the beginnings of human life. In your opinion, is an embryo a human being at the moment of conception?

Some people think that scientists should be allowed to use cells from human embryos for certain types of medical research. Others think this should never be allowed. ... what [do] you think?

Suppose a person has a painful incurable disease. Do you think that doctors should be allowed by law to end the patient's life, if the patient requests it?

Responses to each of these questions were coded on a four-point scale with responses to the two abortion questions running from "always wrong" to "not wrong at all", responses to the question on the beginnings of human life coded as "definitely true" (or untrue) or "probably true" (or untrue), and responses to the remaining two questions coded as "definitely should be allowed" (or should not) and "probably should be allowed" (or should not).

The proportions of people expressing the most 'liberal' responses to each of these questions are shown in Table 5.2. These findings suggest that, rather than the public exhibiting a dogmatic approach to bioethical questions, responses reflect the particular circumstances of each question. Over three-quarters believe that abortion is wrong only "sometimes" or "not at all" if there is a high risk that the baby will have a birth defect. By contrast, only around half believe the same when the issue is limited family finances. There appears to be a preference for reducing suffering: research on embryos (supported by 69 per cent) is justified because, presumably, respondents hope that it will lead to medical breakthroughs regarding conditions such as cystic fibrosis, muscular dystrophy, spinal injuries and diabetes, even though 53 per cent of respondents believe that human life begins at the moment of conception. Similarly, a very large majority ( 82 per cent) believes that a doctor should "probably" or "definitely" be allowed to end the life of a patient with a painful incurable disease at the patient's behest. Views on this issue have changed remarkably little over time (Clery et al., 2007) ranging from 75 per cent support when we first asked the question in 1984 to 82 per cent now.

Not surprisingly, religiosity is strongly associated with people's views on these issues. As Table 5.2 shows, the unreligious are twice as likely as the religious to take the view that an embryo is not a human being at the moment of conception. And the religious are less supportive than the unreligious of abortion on medical grounds. In both cases, the views of the fuzzy faithful lie somewhere in between the two; in relation to abortion they are closer to the unreligious, but they are closer to the religious in their thinking on embryos.

To simplify our analysis we used these five questions to create a scale of attitudes to bioethical issues. Each response was given a score of 1 to 4 , with 1 
Table 5.2 Bioethical attitudes, by religiosity

\begin{tabular}{|c|c|c|c|c|}
\hline \multirow[b]{2}{*}{$\%$ saying ... } & \multicolumn{3}{|c|}{ Religiosity } & \multirow[t]{2}{*}{ All } \\
\hline & Religious & $\begin{array}{c}\text { Fuzzy } \\
\text { faithful }\end{array}$ & $\begin{array}{l}\text { Un- } \\
\text { religious }\end{array}$ & \\
\hline $\begin{array}{l}\text {.. abortion wrong only sometimes or } \\
\text { not at all if strong chance of birth } \\
\text { defect }\end{array}$ & 67 & 81 & 86 & 78 \\
\hline $\begin{array}{l}\text {... abortion wrong only sometimes or } \\
\text { not at all if family cannot afford more } \\
\text { children }\end{array}$ & 35 & 50 & 60 & 49 \\
\hline Base & 531 & 806 & 638 & 1986 \\
\hline $\begin{array}{l}\text {... embryo probably or definitely not a } \\
\text { human being at moment of } \\
\text { conception }\end{array}$ & 30 & 40 & 60 & 43 \\
\hline $\begin{array}{l}\text {... medical research on embryos } \\
\text { should probably or definitely be } \\
\text { allowed }\end{array}$ & 61 & 70 & 77 & 69 \\
\hline $\begin{array}{l}\text {... a doctor should probably or } \\
\text { definitely be allowed to end life of } \\
\text { patient with painful incurable } \\
\text { disease }\end{array}$ & 71 & 85 & 92 & 82 \\
\hline Base & 531 & 810 & 638 & 2250 \\
\hline
\end{tabular}

being the most 'pro-life' and 4 being the most permissive. The maximum score was 20 and the minimum $5 .{ }^{8}$ Table 5.3 shows the average scores for a selection of different religious and demographic groups, with higher scores indicating more liberal attitudes and lower scores indicating less liberal attitudes. That bioethical attitudes are strongly associated with religiosity is scarcely surprising, but it is interesting to note that attitudes vary much more strongly with religiosity than with age - which is often thought to be partly the cause of the less liberal attitudes of the more religious.

These results suggest that religious communities may be a fruitful site of mobilisation for 'pro-life' activists. At present, such mobilisation is relatively limited. During 2007 the Catholic Bishops' Conference of England and Wales lobbied against the requirement that adoption agencies treat same sex couples equally, and has also mobilised adherents against abortion and embryo research, and to support faith schools and reject quotas for the admission of children from other backgrounds. Besides that instance, pro-life and other religious activism does not appear to rely on support from large organisations, and has been primarily through the courts. For example, the rights of students to wear religious dress at school, contravening uniform policy, has been tested in the courts, notably by Lydia Playfoot in 2007. Her campaign to wear a 'purity ring' was funded by the pressure group Christian Concern for our Nation, an 
organisation founded in 2004, which also lobbied Parliament regarding bioethical issues and gay rights during 2007 and $2008 .{ }^{9}$

Table 5.3 Mean scores on bioethical attitudes scale, by respondent characteristics

\begin{tabular}{lcc}
\hline & Mean score & Base \\
All & 14.8 & 1499 \\
Type of religious adherence & & \\
Religious & 13.0 & 392 \\
Fuzzy faithful & 14.9 & 585 \\
Unreligious & 16.2 & 515 \\
Sex & & \\
Male & 15.2 & 682 \\
Female & 14.5 & 817 \\
Age category & & \\
18-24 & 15.1 & 103 \\
65 plus & 14.6 & 331 \\
Education & & \\
Degree & 15.3 & 304 \\
No qualification & 14.3 & 300 \\
\hline
\end{tabular}

\section{Moral values, gender roles and changing family forms}

Religious communities also claim to provide moral guidance on family life and relationships more broadly. The Church of England and Roman Catholic Church justify denominational education on the basis that students are taught according to a distinctive ethos, and a 2008 study of students and parents in faith schools in Bradford found that parents saw the transmission of religious values through faith-based education as a way of providing direction for their children (Howarth et al., 2008). However, religious organisations face a great deal of competition in the provision of moral frameworks. People derive moral values from a variety of sources, including their family during formative years, the media, peers, the law as a frame of reference, and their own individual judgement. At the same time, society has become more complex, particularly with regard to family life, relationships and the place of women in society. Legislative and technological change has led to the role of marriage and family forms evolving considerably. From the 1960s, society has witnessed a fall in marriage rates while divorce has become common; many of those who divorce go on to remarry and their children accordingly enter 'blended families'. The entry of women into higher-paid occupations means that many women can find economic security outside marriage, removing an economic barrier to exiting low-quality relationships. Meanwhile, in 2003 the Employment Equality (Sexual Orientation) Regulations came into force, which rendered it unlawful to 
discriminate against workers because of their sexual orientation and, with the legalising of civil partnerships from 2005, the rights of gay couples have been formally recognised. Accordingly, norms towards family structure, gender roles and gay rights have changed markedly (for example, see Crompton and Lyonette, 2008; Duncan and Phillips, 2008).

How far do such norms vary with religiosity, or has a pragmatic secular norm supplanted traditional mores in order to accommodate these new relationship and household forms? Are those who are more religious more conservative with regard to issues of personal morality, and more supportive of traditional gender roles and family forms? To assess this we look at attitudes towards different forms of sexual relationships as measured by the following questions:

Do you think it is wrong or not wrong ...

... if a man and a woman have sexual relations before marriage?

... a married person having sexual relations with someone other than

his or her husband or wife?

... sexual relations between two adults of the same sex?

Answers were coded on a four-point scale ranging from "always wrong" to "not wrong at all". We also look at answers to this question about traditional gender roles:

Do you agree or disagree: a man's job is to earn money; a woman's job is to look after the home and family?

Table 5.4 shows how responses to these questions vary by religiosity. Unsurprisingly, the religious are the most likely to disagree with pre-marital sex, being ten times more likely than the unreligious to think it is wrong. Only 10 per cent of the fuzzy faithful feel this way. There is also a clear divergence between the religious and unreligious in relation to homosexuality; half of the religious think homosexual behaviour is wrong compared with one in five of the unreligious and just over a third of the fuzzy faithful. By contrast, there is little difference between the three groups in relation to the acceptability of cheating on a partner; a large majority of all groups think that this is wrong. The most religious group are also more likely to support traditional gender roles, with one in five doing so compared with one in ten of the unreligious.

This relationship between religiosity and values holds true even when we take account of other factors such as age. The results of multivariate analysis suggest that the religious are more likely to see homosexual sex as being wrong, even when we control for age and other socio-demographic characteristics such as education. This also holds true for the fuzzy faithful, indicating that even attenuated religiosity has an impact on social attitudes. With regard to gender roles in the home, the religious are more likely than the unreligious to support traditional gender roles, even after controlling for other relevant characteristics, although the fuzzy faithful are no longer significantly different from the unreligious on this issue. 
Table 5.4 Attitudes towards personal and family relationships, by religiosity

\begin{tabular}{|c|c|c|c|c|}
\hline \multirow[b]{2}{*}{$\%$ saying ... } & \multicolumn{3}{|c|}{ Religiosity } & \multirow[t]{2}{*}{ All } \\
\hline & Religious & $\begin{array}{l}\text { Fuzzy } \\
\text { faithful }\end{array}$ & $\begin{array}{l}\text { Un- } \\
\text { religious }\end{array}$ & \\
\hline $\begin{array}{l}\text {... pre-marital sex is always or almost } \\
\text { always wrong }\end{array}$ & 29 & 10 & 3 & 13 \\
\hline $\begin{array}{l}\ldots \text { married person having sex outside } \\
\text { marriage is always or almost always } \\
\text { wrong }\end{array}$ & 90 & 84 & 80 & 84 \\
\hline $\begin{array}{l}\ldots \text { homosexual sex is always or } \\
\text { almost always wrong }\end{array}$ & 50 & 35 & 19 & 34 \\
\hline $\begin{array}{l}\ldots \text { agree that man should earn } \\
\text { money, woman should stay at home }\end{array}$ & 21 & 18 & 10 & 16 \\
\hline Base & 531 & 806 & 638 & 1986 \\
\hline
\end{tabular}

We can also explore how religiosity relates to family formation and parenting responsibilities, by looking at responses to the following question about the role of non-resident parents:

Child maintenance law says that all parents should pay child maintenance even if they did not want to have a child or have not been in a committed relationship. Thinking about a non-resident parent in these circumstances, which of these comes closest to your view?

They are just as responsible for supporting the child compared to other parents

They are partially responsible for supporting the child but not to the same extent as other parents

They are not responsible at all for supporting the child

Here we find near unanimity between the religious, the fuzzy faithful and the unreligious when it comes to the extent to which non-resident parents are responsible for supporting a child born in these circumstances, with around eight in ten taking the view that non-resident parents are either just as responsible as other parents ( 79 per cent) or at least partially responsible (18 per cent). Only a small minority ( 2 per cent) think parents in these circumstances have no responsibilities at all. While religious organisations often promote the dignifying role of motherhood, and portray marriage and the family as the bedrock of society, there is perhaps little social teaching regarding responsibilities to families formed without religious sanction. Broader secular society has evolved norms regarding responsibilities to children - even if this might partly reflect a preference that the taxpayer should not step in where unwilling parents would rather not. 


\section{Party support}

Confessional voting is not thought to characterise electoral behaviour in Britain. But in the European elections of 2009, the Christian Party, established in 2004, garnered 250,000 votes, or 1.6 per cent nationally. While this was not a significant result at the national level, it was nevertheless ahead of the Socialist Labour Party established by Arthur Scargill. The party also polled 2.9 per cent in London. Is this atypical, or does religion play a more general role in voting in Britain?

Traditionally, party support has been viewed as determined primarily by class and economic position. By comparison, many other European countries feature party systems which are two-dimensional, with party divisions based on religious lines as well as class lines. For example, both Germany and the Netherlands host Christian Democratic parties as well as large Social Democratic parties (Oskarsen, 2005). But in Britain, religious cleavages have been viewed as relevant only in Northern Ireland, or as having died with the old Liberal Party in the inter-war period. Before then, Irish Catholics tended to vote Liberal due to their policy on Home Rule. The Liberal Party was also associated with Nonconformism. According to the old adage, the early Labour Party 'owed more to Methodism than Marx'. In 1917, the social worker and preacher Maude Royden memorably called the Church of England 'the Conservative Party at prayer'. ${ }^{10}$ With the collapse of the Liberal Party and the joint dominance of Labour and the Conservatives from the late 1920s, religion was not thought to be significantly associated with party support. Post-war immigrants with a distinct religious profile - such as Irish Catholics or new Commonwealth arrivals - were thought to vote in line with their class position, generally Labour.

However, recent work has suggested that religious faith does have a part to play in British party politics. For example, Kotler-Berkowitz has found that religion was significantly associated with voting behaviour in the 1992 General Election, with examples including a pro-Labour tendency among middle-class Catholics, and a secular middle-class tendency to vote against the Conservative Party (Kotler-Berkowitz, 2001). Middle-class 'Dissenting Protestants' (Methodists and other non-Anglican Protestants) were also found to be more likely to vote Liberal Democrat. Members of small religious communities thought to be generally non-Christian, and likely to be of ethnic minority background - were more likely to vote Labour. Across all respondents, religious behaviour was associated with being less likely to vote Labour and more likely to vote Liberal Democrat. In a further study of the 1992-1997 and 1997-2001 electoral cycles, Andersen et al. (2005) report that religious identification was significant in predicting support for the Conservatives as opposed to Labour from 1997 to 2000, but was not a significant factor from 1992 to 1996 (Andersen et al., 2005).

We asked respondents to recall how they voted in the 2005 General Election. Table 5.5 shows how party choice differed between the religious, the fuzzy faithful and the unreligious. Although there wer some minor variations in party 
support between the different groups, the most obvious finding is that the unreligious were markedly less likely to vote for any party than either the fuzzy faithful or the religious.

Table 5.5 Party voted for in 2005 General Election, by religiosity

\begin{tabular}{lcccc}
\hline & Religious & $\begin{array}{c}\text { Religiosity } \\
\text { Fuzzy } \\
\text { faithful }\end{array}$ & Unreligious & All \\
Party voted for & $\%$ & $\%$ & $\%$ & $\%$ \\
Did not vote & 28 & 28 & 36 & 31 \\
Conservative & 22 & 23 & 17 & 21 \\
Labour & 31 & 27 & 27 & 28 \\
Liberal Democrat & 10 & 7 & 9 & 9 \\
Nationalist parties & 1 & 3 & 2 & 2 \\
Other & 1 & 3 & 3 & 2 \\
Not answered & 6 & 8 & 5 & 7 \\
Base & 302 & 388 & 318 & 302 \\
\hline
\end{tabular}

It is well known that party choice varies according to a wide range of other factors, such as age and education (Evans and Norris, 1999; Clarke et al., 2004). So to examine the independent effect of religiosity while taking account of these sorts of characteristics we used multivariate analysis to predict party support. As the vote choice question was only asked of a subset of respondents in 2008, we used party identification as a proxy for vote choice. ${ }^{11}$ We used multinomial logistic regression to look separately at factors associated with identifying with each of the three main parties compared with not identifying with any party at all. Full details of this analysis can be found in the appendix to this chapter.

We found age to be significant in predicting party identification: older people are more likely to identify with all three of the main parties compared with identifying with none. Income and education are also significant in predicting party identification, with those in higher income quartiles and graduates being more likely to identify with each party (compared with none) than those in the lowest income bracket, or non-graduates. Having a professional or intermediate non-manual occupation as opposed to a routine manual one is also significantly associated with identifying with the Conservatives and Liberal Democrats, but not with Labour. (It is worth noting that education, income and occupation are so interrelated that it is difficult to be absolutely certain of the individual impact of each.) There is no relationship between being a member of an ethnic minority group and identifying with Labour, although ethnicity is significantly associated with not identifying with the Conservatives or the Liberal Democrats. Sex and 
marital status do not appear to make much of a difference to identifying with any of the three main parties.

Even when these factors are taken into account, the religious are more likely than the unreligious to identify with each of the three main parties, suggesting that religiosity is associated with an increased chance of identifying with any party rather than none. Multivariate analysis confirms this. It is not possible to say for sure what is behind this link between religiosity and party identification. However, if we repeat the analysis while distinguishing between the three dimensions of religiosity discussed earlier - generalised religiosity, 'believing without belonging', and the nominal religiosity associated with religious background - religious background emerges as the main component significantly associated with party identification. It may be that our measure of religious background is capturing the role of family socialisation in general rather than religious socialisation per se.

\section{Social trust}

Finally, we explore the question of social trust and whether this varies according to religiosity. In many studies of the decline of traditional community spirit and the emergence of new forms of belonging, 'generalised social trust' is used as an indicator of 'social capital', the bonds and social networks thought to be the basic pre-requisite for democracy to function fully (Putnam, 2000). Religious life provides one site for social capital and so might be expected to be associated with higher levels of civic engagement and social trust. The Saguaro Seminar on Civic Engagement's Better Together report, for example, found that in the US "houses of worship build and sustain more social capital - and social capital of more varied forms - than any other type of institution in America". ${ }^{12}$

Although the UK is more secular than the US, we might expect that here too those who are religious might have higher levels of social trust than the less religious. There are numerous possible explanations for this. Many religions encourage people to promote the interests of others or the common good ahead of their own narrow self-interest. In addition, the social aspects of religion bring people into contact with others more often, so that they learn through experience that others are willing to cooperate and are fundamentally trustworthy. Religious organisations can increase a sense of connectedness and community, and encourage people to act cooperatively. Religious practice in communal settings also reflects social capital investments already made. Perhaps religion provides a 'psychic insurance' effect in people's dealings with others, which makes them more willing to take a risk that others will act reciprocally (Kirkpatrick, 2005; Scheve and Stasavage, 2006).

Conversely, however, some argue that religious practice can promote only socialising with people from the same social or ethnic group, and that in fact divisions between such groups are entrenched. It has also been suggested that spending time on religious activities reduces productivity and the time available to engage in other, more trust-building, activities (Alexander, 2007). In this 
sense, religiosity might be associated with lower trust - as happens in sectarian societies. Some faith groups are hierarchical and authoritarian, and promote less civic engagement rather than more (Putnam, 1993). Furthermore, to the extent that religiosity is increasingly individualistic and personalised, the link between religion and social capital is weakened (Putnam, 2000). Finally, a third strand of the literature suggests that in Europe the link between religion and social capital is 'generally unsubstantial' (Halman and Petterson, 2001). This is because of the secularisation process in Europe: religion has increasingly less impact on public and social life, and has become increasingly privatised and personalised.

To measure social trust, we ask the following question:

Generally speaking, would you say that most people can be trusted or that you can't be too careful in dealing with people?

Under half - 45 per cent - respond by saying that most people can "almost always" or "usually" be trusted.

We found no significant relationship between religiosity (whether measured by our threefold typology or the fuller religiosity scale) and social trust. This may be because these measures of religiosity do not capture the social aspects of religion which might correlate more strongly with social capital. Alternatively, it may also reflect the fact that the measure of generalised social trust does not capture the variation in social capital which is associated with religious belief and practice: religious people may be strongly community minded and exhibit high levels of volunteering and reciprocity, without responding that people can generally be trusted. Finally, of course, there may simply be little or no relationship in Britain between generalised social trust and religiosity.

Multivariate analysis was carried out to examine the effect of religiosity, measured by the threefold typology, while controlling for various demographic and socio-economic factors. Full details can be found in the appendix to this chapter. Holding a degree, or being in the top income quartile are significantly positively associated with social trust, as is having a professional or intermediate job compared with a routine job. However, the most religious of our three categories are no more or less trusting than the unreligious, while the fuzzy faithful have slightly lower levels of social trust than the unreligious. Similar findings also applied when using the religiosity scale. There is little evidence, then, for the religious having higher levels of social trust than the unreligious, at least in Britain.

\section{Conclusions}

In this chapter we have examined whether religion still plays a role in shaping attitudes in British society. In certain aspects the highly religious are distinctive: they are more likely to be 'pro-life' and to exhibit less liberal attitudes towards 
abortion and voluntary euthanasia. They are more traditional in their views about gender roles and are much less liberal than the unreligious about homosexuality. These differences appear to hold even when controlling for confounding variables such as age.

In other regards, it is less clear that the religious are different. Religiosity does appear to be associated with political engagement, as measured via party identification. However, on the basis of the analysis included in this chapter it is not possible for us to be sure why this might be the case. Using more sophisticated measures of religiosity, it appears that religiousness in itself is not associated with the tendency to identify with any party compared with none. Instead, the relationship seemed to work through 'religious background', or a nominal type of religiosity which could be capturing family socialisation effects. Finally, we did not find any clear link between religiosity and generalised social trust. It may be that examining friendship or membership of voluntary associations would prove more fruitful in clarifying how religion might bring people together in modern Britain, but this awaits further study.

Perhaps these results are not surprising. British society has become increasingly secular over time. Despite the post $7 / 7$ discourse regarding 'religious polarisation' and government engagement with religious groups, the vast majority of people do not attend church regularly or subscribe to strong religious beliefs. Even for those who practise, religion appears to be a private matter. Religious organisations do have a 'comparative advantage' with regard to bioethical questions, since most religions have a clear position on the parameters of life which scientists perhaps struggle to communicate in like manner. But on the evidence presented here, it is difficult to be certain that religion in Britain affects socio-political attitudes more widely.

\section{Notes}

1. Prior to the 2001 Census, evidence on growth of other world religions in Britain depended on opinion poll data, data on ethnicity and official data on number of religious buildings. Peach (1996) provides an overview of post-war British immigration, while Peach and Gale (2005) provide measures of the growth of Muslim, Sikh and Hindu places of worship. The growth in number of places of worship for 'other Christian' denominations from 1972 to 2004 has been documented in Weller (2007: 42). Meanwhile, Brierley (1998-2008) suggests that membership of pentecostalist churches has grown significantly. Survey evidence suggests that the transmission rate of religious identification between the first generation of immigrants and their children is high. Even if religiosity is on average lower for second-generation immigrants compared with their parents, their religiosity is higher than that of the white majority group, and this group is a growing proportion of the population. See, for example, Kaufmann (2007).

2. Human Fertilisation and Embryology Bill [HL] 2007-08. The Bill was first introduced to Parliament in November 2007; the eventual Human Fertilisation and Embryology Act 2008 (c.22) received Royal Assent in November 2008. 
3. The data suggest that respondents are slightly more likely to accept that an afterlife exists than heaven, and in turn are more likely to accept that heaven exists than hell. Nine per cent of respondents consider that an afterlife exists but that heaven does not, while 11 per cent of respondents consider that heaven exists but that hell does not. This gives us confidence that the three items should be included separately. This is borne out by the fact that the mean score on the religiosity scale for those believing in the afterlife is lower than the score for the respondents who believe in heaven (which in turn is lower than the scores for those who believe in hell).

4. The usual method of testing whether such a scale is a reliable indicator of an underlying attitude is Cronbach's alpha. Cronbach's alpha for the fourteen items was 0.87 , which indicates a very good level of reliability.

5. We used categorical principal components analysis, which reduces a large number of variables down to a smaller number of uncorrelated 'components' or dimensions. The categorical principal components analysis (CATPCA) method, in particular, suits data which are dichotomous or in ordered categories, rather than continuous measures. Full details of the results of the CATPCA analysis can be found in the appendix to this chapter.

6. This term was coined by Grace Davie, the leading exponent of the hypothesis that 'believing without belonging' characterises religiosity in Britain today (Davie, 1994).

7. There is a further practical distinction between our different measures of religiosity: sample size. While the typology is the simplest measure of religiosity, it does have the advantage of including the largest number of respondents $(4,201)$. By contrast, the religiosity scale and the three component scores cover only 1,951 respondents. In order to maximise the number of respondents for whom we could calculate scale scores, we included cases where the respondent had responded to at least 11 of the 14 items, and in these cases replaced missing observations for the remaining items with the variable mean. The CATPCA procedure used the same set of cases, but instead treated missing values 'passively'; missing values were ignored in the analysis rather than imputations made. The inclusion of sets of responses where only three or fewer responses were missing ensured that valuable information was not lost, while imputation or non-inclusion was kept to a reasonable level.

8. In this instance, "don't know", "can't choose" and "refusal" responses were excluded. Cronbach's alpha for this scale was 0.67 , indicating moderate internal consistency, which might be expected given that the scale is based on a small number of items. However, it suggests that analysis should be interpreted with some caution. (The score did not increase when individual items were dropped.)

9. As reported by BBC News in 2007 ("Chastity Ring' Girl Loses Case", available at http://news.bbc.co.uk/1/hi/uk/6900512.stm).

10. As reported in The Times in 1917 ('Church Reform. Restricted Spiritual Activity. The Demand For Freedom', 17th July).

11. Further details of the questions used to measure party identification can be found in Appendix I of this report.

12. Saguaro Seminar on Civic Engagement, Kennedy School of Government, Harvard University, Better Together (December 2000: 63). First edition of report available at http://www.bettertogether.org/pdfs/FullReportText.pdf 
13. Two measures of social trust were included on the 2008 survey, one asked face to face and the other (described here) in a self-completion supplement. A slightly lower measure of social trust (40 per cent) was obtained on the face-to-face version of the question.

\section{References}

Alexander, M. (2007), 'Determinants of Social Capital: New Evidence on Religion, Diversity and Structural Change', British Journal of Political Science, 37: 368-377

Andersen, A., Tilley, J. and Heath, A.F. (2005), 'Political Knowledge and Enlightened Preferences: Party Choice through the Electoral Cycle', British Journal of Political Science, 35: 285-302

Branas-Garza, P., Garcia, T. and Neuman, S. (forthcoming), 'The Big Carrot: HighStakes Incentives Revisited', Journal of Behavioral Decision Making

Brierley, P. (ed.) (1998-2008), Religious Trends, London: Christian Research

Clarke, H., Sanders, D., Stewart, M. and Whiteley, P. (2004), Political Choice in Britain, Oxford: Oxford University Press

Clery, E., McLean, S. and Phillips, M. (2007), 'Quickening death: the euthanasia debate', in Park, A., Curtice, J., Thomson, K., Phillips, M. and Johnson, M. (eds.), British Social Attitudes: the $23^{\text {rd }}$ Report - Perspectives on a Changing Society, London: Sage

Crockett, A. and Voas, D. (2006), 'Generations of Decline: Religious Change in $20^{\text {th }}$ Century Britain', Journal for the Scientific Study of Religion, 45(4): 567-584

Crompton, R. and Lyonette, C. (2008), 'Who does the housework? The division of Labour within the home', in Park, A., Curtice, J., Thomson, K., Phillips, M., Johnson, M. and Clery, E. (eds.), British Social Attitudes: the $24^{\text {th }}$ Report, London: Sage

Davie, G. (1994), Religion in Britain since 1945: Believing without Belonging, Oxford: Blackwell

Duncan, S. and Phillips, M. (2008), 'New families? Tradition and change in modern relationships', in Park, A., Curtice, J., Thomson, K., Phillips, M., Johnson, M. and Clery, E. (eds.), British Social Attitudes: the $24^{\text {th }}$ Report, London: Sage

Evans, G. and Norris, P. (eds.), (1999), Critical Elections: British Parties and Voters in Long-Term Perspective, London: Sage

Glock, C.Y. (1962), 'On the Study of Religious Commitment', Review of Recent Research Bearing on Religious and Character Formation, supplement to Religious Education, 57(4): 98-110

Glock, C.Y. and Stark, R. (1968), American Piety: The Nature of Religious Commitment, Berkley: University of California Press

Halman, L. and Petterson, T. (2001), 'Religion and Social Capital in Contemporary Europe: Results from the 1999/2000 European Values Study’, Research in the Social Scientific Study of Religion, $12: 65-93$

Howarth, J., Lees, J., Sidebotham, P., Higgins, J. and Imtiaz, A. (2008), Religion, Beliefs and Parenting Practices, York: Joseph Rowntree Foundation

Kaufmann, E. (2007), 'Shall the Religious Inherit the Earth?: Demography and Politics in the Twenty-First Century', Working Paper, Birkbeck College, London 
Kirkpatrick, L.A. (2005), Attachment, Evolution, and the Psychology of Religion, New York: Guilford Publications

Kotler-Berkowitz, L.A. (2001), 'Religion and Voting Behaviour in Great Britain: A Reassessment', British Journal of Political Science, 31(3): 523-555

Leege, D.C. and Kellstedt L.A. (eds.) (1993), Rediscovering the Religious Factor in American Politics, Armonk, NY: M.E. Shape

Nicolet, S. and Tresch, A. (2009), 'Changing Religiosity, Changing Politics? The Influence of "Belonging" and "Believing" on Political Attitudes in Switzerland', Politics and Religion, 2: 76-99

Oskarson, M. (2005), 'Social Structure and Party Choice', in Thomassen, J. (ed.), The European Voter: A Comparative Study of Modern Democracies, Oxford: Oxford University Press

Peach, C. (ed.) (1996), Ethnicity in the 1991 Census: Volume Two: The ethnic minority populations of Great Britain, London: The Stationery Office

Peach, C. and Gale, R. (2005), 'Muslims, Hindus and Sikhs in the New Religious Landscape of England', The Geographical Review, 93(4): 469-490

Putnam, R.D. (2000), Bowling Alone: The Collapse and Revival of American Community, New York: Simon and Schuster

Putnam, R.D. with Leonardi, R. and Nanetti, R.Y. (1993), Making Democracy Work: Civic Traditions in Modern Italy, Princeton: Princeton University Press

Scheve, K. and Stasavage, D. (2006), 'Religion and Preferences for Social Insurance', Quarterly Journal of Political Science, 1(3): 255-286

Voas, D. (2009), 'The Rise and Fall of Fuzzy Fidelity in Europe', European Sociological Review, 25(2): 155-168

Weller, P. (2007), Religions in the UK Directory: 2007-2010, Derby: Multi-Faith Centre

\section{Acknowledgements}

The National Centre for Social Research is grateful to the Economic and Social Research Council for the financial support (grant number RES-501-25-001) which allowed us to ask the International Social Survey Programme (ISSP) questions reported in this chapter. We are also grateful to the John Templeton Foundation (grant number 13362) and NORFACE for funding the additional questions about religion reported here. Responsibility for the analysis of these data lies solely with the author. 


\section{Appendix}

\section{The religiosity scale}

When calculating the religiosity scale, indicators based on responses to the following questions were used:

Do you regard yourself as belonging to any particular religion; which?

Yes (any) $=1$, No $=0$

In what religion, if any, were you brought up: what was your family's religion?

Brought up in any religion $=1$, No religion $=0$

Apart from such special occasions as weddings, funerals and baptisms, how often nowadays do you attend services or meetings connected with your religion? [once a week or more, less often but at least once in two weeks, less often but at least once a month, less often but at least twice a year, less often but at least once a year, less often, never or practically never, varies too much to say]

At least once a month $=1$, Less often $=0$

How often do you take part in the activities or organisations of a church or place of worship other than attending services? [never, less than once a year, about once or twice a year, several times a year, about once a month, two to three times a month, nearly every week, every week, several times a week]

Any participation $=1$, Never $=0$

How important is religion in your daily life?[Version A/B: very important, somewhat important, not very important, not at all important; Version C/D: extremely important, very important, somewhat important, not at all important]

At least somewhat important $=1$, Other response $=0$

Would you describe yourself as religious? [extremely religious, very religious, somewhat religious, neither religious nor non-religious, somewhat non-religious, very non-religious, extremely non-religious]

At least somewhat religious $=1$, Other response $=0$

Now thinking about the present, about how often do you pray? [never, less than once a year, about once or twice a year, several times a year, about once a month, 2-3 times a month, nearly every week, every week, several times a week, once a day, several times a day]

Ever pray (even if less than once a year) $=1$, Never $=0$

Which statement comes closest to expressing what you believe about God? [I don't believe in God, I don't know whether there is a God and I don't believe there is any way to find out, I don't believe in a personal God but I do believe in a higher power of some kind, I find myself believing in God some of the time but not at others, while I have doubts I feel that I do believe in God, or I know God really exists and that I have no doubts about it?]

Believe in God at least some of the time $=1$, Do not believe in a personal God $=0$ 
Are you absolutely sure you believe in God, somewhat sure, not quite sure, not at all sure, or are you sure you do not believe in God?

Absolutely or somewhat sure $=1$, Other response $=0$.

Do you believe in heaven? [yes definitely, yes probably, no probably not, no definitely not]

Yes $=1$, No $=0$

Do you believe in hell? [yes definitely, yes probably, no probably not, no definitely not]

Yes $=1$, No $=0$

Do you believe in life after death? [yes definitely, yes probably, no probably not, no definitely not]

Yes $=1$, No $=0$

How much confidence do you have in churches and religious organisations? [complete confidence, a great deal of confidence, some confidence, very little confidence, no confidence at all]

At least some confidence $=1$, Other response $=0$

Please consider and tell me if you agree or disagree: we trust too much in science and not enough in religious faith? [strongly agree, agree, neither agree nor disagree, disagree, strongly disagree]

Agree/strongly agree $=1$, Other response $=0$

Do you agree or disagree that practising a religion helps people to find inner peace and happiness? [strongly agree, agree, neither agree nor disagree, disagree, strongly disagree]

Agree/strongly agree $=1$, Other response $=0$

Table A.1 gives the proportions scoring 1 for each item.

Table A.1 Responses to dichotomised items in the religiosity scale

\begin{tabular}{lcc}
\hline & $\begin{array}{c}\text { \% } \\
\text { respondents }\end{array}$ & Base \\
Religious adherent & 56 & 4464 \\
Was brought up in religion & 87 & 4470 \\
Attends church at least monthly & 20 & 3960 \\
Takes part in church activities at least occasionally & 38 & 1951 \\
Reports religion at least somewhat important in daily life & 40 & 4486 \\
Describes self as at least somewhat religious & 38 & 1891 \\
Prays at least occasionally & 56 & 1937 \\
Believes in God at least somewhat & 48 & 4222 \\
Believes heaven exists (probably or definitely) & 48 & 1703 \\
Believes hell exists (probably or definitely) & 28 & 1986 \\
Believes life exists after death (probably or definitely) & 52 & 1737 \\
Has at least some confidence in churches & 50 & 1986 \\
Agrees/strongly agree we trust too much in science & 15 & 1986 \\
Agrees/strongly agree religion helps people find peace & 65 & 1507 \\
\hline
\end{tabular}


Tables A.2 summarise the distribution of respondents along the religiosity scale, as shown in Figure 5.1.

Table A.2 Religiosity scale: Proportion of respondents given each score

\begin{tabular}{lcc}
\hline Score on religiosity scale & \% of respondents & Base \\
0 & 1 & 15 \\
1 & 6 & 101 \\
2 & 12 & 228 \\
3 & 10 & 200 \\
4 & 8 & 170 \\
5 & 8 & 154 \\
6 & 8 & 168 \\
7 & 7 & 125 \\
8 & 7 & 141 \\
9 & 6 & 113 \\
10 & 7 & 131 \\
11 & 8 & 139 \\
12 & 6 & 115 \\
13 & 5 & 103 \\
14 & 3 & 48 \\
Total & 100 & 1951 \\
\hline
\end{tabular}




\section{Categorical principal components analysis}

Table A.3 Component loadings for each of the three dimensions of religiosity, by variable

\begin{tabular}{|c|c|c|c|}
\hline & $\begin{array}{l}\text { Generalised } \\
\text { religiosity }\end{array}$ & $\begin{array}{l}\text { Belief without } \\
\text { belonging }\end{array}$ & $\begin{array}{l}\text { Religious } \\
\text { background }\end{array}$ \\
\hline Whether respondent is religious adherent & 0.71 & -0.09 & 0.37 \\
\hline Importance of religion in respondent's daily life & 0.77 & -0.30 & -0.01 \\
\hline \multicolumn{4}{|l|}{ Whether respondent brought up with religious } \\
\hline affiliation & 0.33 & 0.09 & 0.86 \\
\hline Respondent perception of how religious they are & 0.90 & -0.09 & 0.07 \\
\hline Whether respondent believes in God & 0.78 & 0.01 & 0.11 \\
\hline Frequency of church attendance & 0.70 & -0.47 & -0.41 \\
\hline Frequency of prayer & 0.87 & -0.16 & 0.02 \\
\hline Belief in afterlife & 0.68 & 0.55 & -0.20 \\
\hline Church activity outside regular services & 0.69 & -0.48 & -0.23 \\
\hline $\begin{array}{l}\text { Whether respondent thinks religion helps people find } \\
\text { inner peace }\end{array}$ & 0.33 & -0.11 & 0.17 \\
\hline Whether respondent thinks we trust too much in & & & \\
\hline science, not enough in religion & 0.55 & 0.02 & 0.05 \\
\hline Whether respondent has confidence in churches & 0.61 & 0.00 & 0.16 \\
\hline Belief in heaven & 0.81 & 0.49 & -0.18 \\
\hline Belief in hell & 0.70 & 0.55 & -0.23 \\
\hline Cronbach's alpha & 0.9 & 0.3 & 0.3 \\
\hline Eigenvalue & 6.7 & 1.4 & 1.3 \\
\hline Base & 1951 & & \\
\hline
\end{tabular}

\section{Regression analysis: Religion and party identification}

Tables A.4 to A.6 show the results of a multinomial logistic regression analysis looking at whether the respondent has a particular party identification compared with no party identification. Table A.7 show the results of a binomial logistic regression analysis where the dependent variable is respondent has any party identification $v s$. none. In each case a positive coefficient indicates that the group is more likely than the reference group (shown in brackets) to identify with the party, while a negative coefficient indicates the group is less likely than the reference group to identify with the party. More details of logistic regression techniques can be found in Appendix I of the report. 
Table A.4 Respondent identifies with Labour vs. no party identification multinomial logistic regression

\begin{tabular}{|c|c|c|c|}
\hline Intercept & $\begin{array}{l}\text { Coefficient } \\
1.318^{\star \star}\end{array}$ & $\begin{array}{c}\text { Standard error } \\
0.233\end{array}$ & $\begin{array}{l}\text { p value } \\
0.000\end{array}$ \\
\hline $\begin{array}{l}\text { Age (increase by one year) } \\
\text { Religiosity (unreligious) }\end{array}$ & $0.030^{\star *}$ & 0.004 & 0.000 \\
\hline Religious & $0.788^{* *}$ & 0.161 & 0.000 \\
\hline $\begin{array}{l}\text { Fuzzy faithful } \\
\text { Sex (male) }\end{array}$ & $0.369^{* *}$ & 0.128 & 0.004 \\
\hline $\begin{array}{l}\text { Female } \\
\text { Married (no) }\end{array}$ & -0.187 & 0.115 & 0.105 \\
\hline $\begin{array}{l}\text { Yes } \\
\text { Ethnicity (white) }\end{array}$ & -0.093 & 0.124 & 0.453 \\
\hline $\begin{array}{l}\text { Non-white } \\
\text { Income (lowest quartile) }\end{array}$ & 0.077 & 0.211 & 0.714 \\
\hline $\begin{array}{l}\text { Second quartile } \\
\text { Third quartile }\end{array}$ & $\begin{array}{r}-0.016 \\
0.140\end{array}$ & $\begin{array}{l}0.158 \\
0.168\end{array}$ & $\begin{array}{l}0.918 \\
0.403\end{array}$ \\
\hline $\begin{array}{l}\text { Highest quartile } \\
\text { Education (below degree) }\end{array}$ & $0.503^{\star *}$ & 0.198 & 0.011 \\
\hline $\begin{array}{l}\text { Degree } \\
\text { Occupation (routine) }\end{array}$ & $0.742^{* *}$ & 0.180 & 0.000 \\
\hline Professional or managerial & 0.158 & 0.148 & 0.283 \\
\hline Intermediate & 0.015 & 0.152 & 0.921 \\
\hline Nagelkerke R2 & 0.15 & & \\
\hline Base $=3283$ & & & \\
\hline
\end{tabular}

* = significant at $95 \%$ level; ${ }^{*}=$ significant at $99 \%$ level

Table A.5 Respondent identifies with Conservatives vs. no party identification multinomial logistic regression

\begin{tabular}{|c|c|c|c|}
\hline & Coefficient & Standard error & $p$ value \\
\hline Intercept & $0.855^{\star *}$ & 0.236 & 0.000 \\
\hline $\begin{array}{l}\text { Age (increase by one year) } \\
\text { Religiosity (unreligious) }\end{array}$ & $0.043^{\star *}$ & 0.004 & 0.000 \\
\hline Religious & $0.872^{* *}$ & 0.161 & 0.000 \\
\hline Fuzzy faithful & $0.494^{* *}$ & 0.128 & 0.000 \\
\hline $\begin{array}{l}\text { Sex (male) } \\
\text { Female }\end{array}$ & $-0.218^{*}$ & 0.115 & 0.058 \\
\hline Married (no) & & & \\
\hline $\begin{array}{l}\text { Yes } \\
\text { Ethnicity (white) }\end{array}$ & 0.017 & 0.125 & 0.893 \\
\hline $\begin{array}{l}\text { Non-white } \\
\text { Income (lowest quartile) }\end{array}$ & $-0.812^{* \star}$ & 0.243 & 0.001 \\
\hline Second quartile & $0.375^{\star *}$ & 0.161 & 0.020 \\
\hline Third quartile & $0.756^{\star *}$ & 0.169 & 0.000 \\
\hline $\begin{array}{l}\text { Highest quartile } \\
\text { Education (below degree) }\end{array}$ & 1.180 & 0.198 & 0.000 \\
\hline $\begin{array}{l}\text { Degree } \\
\text { Occupation (routine) }\end{array}$ & $0.352^{*}$ & 0.180 & 0.051 \\
\hline Professional or managerial & $0.750^{* *}$ & 0.146 & 0.000 \\
\hline Intermediate & $0.764^{\star *}$ & 0.148 & 0.000 \\
\hline Nagelkerke R2 & 0.15 & & \\
\hline Base $=3283$ & & & \\
\hline
\end{tabular}

${ }^{*}=$ significant at $95 \%$ level; ${ }^{*}=$ significant at $99 \%$ level 
Table A.6 Respondent identifies with Liberal Democrats vs. no party identification multinomial logistic regression

\begin{tabular}{|c|c|c|c|}
\hline Intercept & $\begin{array}{l}\text { Coefficient } \\
-0.904^{* *}\end{array}$ & $\begin{array}{c}\text { Standard error } \\
0.309\end{array}$ & $\begin{array}{c}\text { p value } \\
0.003\end{array}$ \\
\hline $\begin{array}{l}\text { Age (increase by one year) } \\
\text { Religiosity (unreligious) }\end{array}$ & $0.033^{* *}$ & 0.005 & 0.000 \\
\hline Religious & $0.570^{* *}$ & 0.199 & 0.004 \\
\hline $\begin{array}{l}\text { Fuzzy faithful } \\
\text { Sex (male) }\end{array}$ & 0.130 & 0.167 & 0.438 \\
\hline $\begin{array}{l}\text { Female } \\
\text { Married (no) }\end{array}$ & 0.188 & 0.151 & 0.213 \\
\hline $\begin{array}{l}\text { Yes } \\
\text { Ethnicity (white) }\end{array}$ & -0.120 & 0.162 & 0.456 \\
\hline $\begin{array}{l}\text { Non-white } \\
\text { Income (lowest quartile) }\end{array}$ & $-0.788^{* *}$ & 0.323 & 0.015 \\
\hline Second quartile & $0.483^{\star \star}$ & 0.211 & 0.022 \\
\hline Third quartile & $0.757^{* *}$ & 0.222 & 0.001 \\
\hline $\begin{array}{l}\text { Highest quartile } \\
\text { Education (below degree) }\end{array}$ & $0.778^{* *}$ & 0.260 & 0.003 \\
\hline $\begin{array}{l}\text { Degree } \\
\text { Occupation (routine) }\end{array}$ & $1.054^{\star *}$ & 0.209 & 0.000 \\
\hline Professional or managerial & $0.632^{* *}$ & 0.189 & 0.001 \\
\hline Intermediate & $0.497^{* *}$ & 0.198 & 0.012 \\
\hline Nagelkerke R2 & 0.15 & & \\
\hline Base $=3283$ & & & \\
\hline
\end{tabular}

* = significant at $95 \%$ level; ${ }^{* *}=$ significant at $99 \%$ level

Table A.7 Respondent identifies with any party vs. no party identification logistic regression

\begin{tabular}{|c|c|c|c|}
\hline & Coefficient & Standard error & $p$ value \\
\hline Intercept & $1.940^{* *}$ & 0.215 & 0.000 \\
\hline $\begin{array}{l}\text { Age (increase by one year) } \\
\text { Religiosity (unreligious) }\end{array}$ & $0.033^{* *}$ & 0.003 & 0.000 \\
\hline Religious & $0.666^{\star *}$ & 0.147 & 0.000 \\
\hline Fuzzy faithful & $0.349^{* *}$ & 0.115 & 0.002 \\
\hline $\begin{array}{l}\text { Sex (male) } \\
\text { Female } \\
\text { Married (no) }\end{array}$ & -0.167 & 0.102 & 0.103 \\
\hline $\begin{array}{l}\text { Yes } \\
\text { Ethnicity (white) }\end{array}$ & -0.084 & 0.112 & 0.456 \\
\hline $\begin{array}{l}\text { Non-white } \\
\text { Income (lowest quartile) }\end{array}$ & $-0.390^{* *}$ & 0.190 & 0.040 \\
\hline Second quartile & 0.133 & 0.145 & 0.358 \\
\hline Third quartile & $0.383^{* *}$ & 0.149 & 0.010 \\
\hline Highest quartile & $0.700^{* *}$ & 0.170 & 0.000 \\
\hline Education (below degree) & & & \\
\hline $\begin{array}{l}\text { Degree } \\
\text { Occupation (routine) }\end{array}$ & $0.670^{* *}$ & 0.161 & 0.000 \\
\hline Professional or managerial & $0.670^{* *}$ & 0.161 & 0.000 \\
\hline Intermediate & $0.434^{* *}$ & 0.133 & 0.001 \\
\hline Nagelkerke R2 & 0.12 & & \\
\hline
\end{tabular}

${ }^{*}=$ significant at $95 \%$ level; ${ }^{* *}=$ significant at $99 \%$ level 


\section{Regression analysis: Religion and social trust}

Table A.8 shows the results of a logistic regression analysis looking at social trust. The dependent variable is coded so that $1=$ respondent thinks people can always or usually be trusted and $0=$ respondent thinks "you can't be too careful". In each case a positive coefficient indicates that the group is more likely than the reference group (shown in brackets) to trust other people, while a negative coefficient indicates the group is less likely than the reference group to trust other people.

Table A.8 Respondent thinks most people can be trusted vs. "you can't be too careful" logistic regression

\begin{tabular}{|c|c|c|c|}
\hline Intercept & $\begin{array}{l}\text { Coefficient } \\
-0.799^{* *}\end{array}$ & $\begin{array}{c}\text { Standard error } \\
0.217\end{array}$ & $\begin{array}{c}\text { p value } \\
0.000\end{array}$ \\
\hline $\begin{array}{l}\text { Age (increase by one year) } \\
\text { Religiosity (unreligious) }\end{array}$ & $0.013^{* *}$ & 0.003 & 0.000 \\
\hline Religious & 0.075 & 0.141 & 0.594 \\
\hline $\begin{array}{l}\text { Fuzzy faithful } \\
\text { Sex (male) }\end{array}$ & $-0.210^{*}$ & 0.122 & 0.086 \\
\hline $\begin{array}{l}\text { Female } \\
\text { Married (no) }\end{array}$ & -0.130 & 0.107 & 0.225 \\
\hline $\begin{array}{l}\text { Yes } \\
\text { Ethnicity (white) }\end{array}$ & 0.123 & 0.116 & 0.287 \\
\hline $\begin{array}{l}\text { Non-white } \\
\text { Income (lowest quartile) }\end{array}$ & 0.146 & 0.219 & 0.505 \\
\hline Second quartile & 0.190 & 0.148 & 0.200 \\
\hline Third quartile & 0.056 & 0.161 & 0.729 \\
\hline $\begin{array}{l}\text { Highest quartile } \\
\text { Education (below degree) }\end{array}$ & $0.477^{* *}$ & 0.184 & 0.009 \\
\hline $\begin{array}{l}\text { Degree } \\
\text { Occupation (routine) }\end{array}$ & $0.605^{\star *}$ & 0.149 & 0.000 \\
\hline Professional or managerial & $0.467^{\star *}$ & 0.133 & 0.000 \\
\hline Intermediate & $0.564^{* *}$ & 0.139 & 0.000 \\
\hline Nagelkerke R2 & 0.09 & & \\
\hline Base $=1633$ & & & \\
\hline
\end{tabular}

${ }^{*}=$ significant at $95 \%$ level; ${ }^{*}=$ significant at $99 \%$ level 
